\title{
Johtajuus rakentuu joka hetki
}

Birgitta Romppainen \& Anita Kallasvuo (2011). Johtajuuden rakentuminen.

Eväitä lähijohtamiseen. Kansanvalistusseura. 223 s.

Monissa viime vuosien johtamisopeissa korostuu usko näyttäviin johtamisoperaatioihin, jatkuvaan ja jopa itsetarkoitukselliseen muutokseen sekä krooniseen innovointiin perustyön kustannuksella. Usein johtamiskirjallisuuden tyylilajiksi valitaan maaginen konsulttikieli, abstrakti muutospuhe ja turvallinen lintuperspektiivi organisaatioon. Ongelmat näyttäytyvät muutosvastarintana, tehottomana strategiana tai riittämättömänä viestintänä ylhäältä alaspäin.

Vastapainona valmiita ratkaisuja tarjoaville johtamisopeille voisi olla Harri Hyypän toteamus: johtajan ensisijainen ja luovuttamaton tehtävä on ajatella. Johtamisajattelu voi perustua vain organisaationäkemykselle. Erilaisten paineiden puristuksissa esimiesten ja johtajien mahdollisuudet omaan ajatteluun kuitenkin vaarantuvat. (Osviitta 2/09.)

Birgitta Romppainen ja Anita Kallasvuo ovat työnohjaajia ja johdon valmentajia. Johtajuuden rakentuminen -teos sai alkunsa 20 vuoden keskusteluista johtajien kanssa - lähiesimiesten arkisista ongelmista ja koetuista rooliristiriidoista. Teos ei siten ole kirjoittajiensa teoriaoppineisuuden osoitus tai muutosmaaginen julistus. Lukijaa puhuttelee kokemukseen pohjautuva ja puheenomainen sävy samaan tapaan kuin esimerkiksi Satu Kasken ja Tuula
Kianderin teoksissa Tunnejohtajuus ja Minä johtajana.

Lähiesimiehen tulisi kuunnella sekä ylempää johtoa että työyhteisöä. Ristiriitaisissa rooleissaan lähiesimies voi Romppaisen ja Kallasvuon mukaan joutua huomaamattaan monenlaisiin ansoihin, kuten pelastaminen, itsensä korostaminen, toisten vähättely, hyökkäys ja puolustus, kostaminen, kontrolli, selittely, syyllistäminen, teflonpintaisuus, torjuminen ja välttely.

Johtajaan kohdistuu myös epärealistisia odotuksia. Voidaan odottaa, että esimies olisi työtoveri, yksi meistä. Lähiesimiehen odotetaan olevan aina käytettävissä, mutta jos hän 'jalkautuu' yhteisöön, hänet voidaankin kokea kyttääjäksi. Lähiesimiehen tulisi ratkaista ongelmat kertaheitolla, jopa ilman ongelmien nostamista esiin.

Työntekijöiden sitoutuminen rakentuu antamisen ja saamisen tasapainolle. Lähijohtajan työssä on kirjoittajien mukaan keskityttävä työyhteisön pitämiseen päätehtävissään, työskentelyolosuhteiden luomiseen, työntekijöiden kuuntelemiseen ja ohjaamiseen sekä arkisten työn ongelmien ratkaisemiseen.

Työyhteisön henkilökemiana näyttäytyvien ongelmien taustalla ovat monesti epäselvät roolit, rajat ja muut rakenteet. Työyhteisössä on voitava riittävästi keskustella ongelmista, epäselvyyksistä sekä työn- ja vastuiden jaosta. Kun jokainen tietää vastuunsa rajat, omat ja toisten ammatilliset roolit rakentuvat selkeiksi.

Myös Jaakko Koivumäen väitöstutkimuksen mukaan työntekijät kaipaavat lähityöyhteisössään työnjaollista selkeyttä, selviä sääntöjä ja määrätietoista johtajuutta reaktiona organisaatiotason kaaokseen. Työn vakauden ja ennakoitavuuden puute näyttää olevan keskeinen tekijä, joka synnyttää epäluottamusta ylimpään johtoon.

Johtamisen periaatteista puhutaan harvoin koko työyhteisön kesken. Romppainen ja Kallasvuo antavat toimivan tuntuisen neuvon lähijohtajille omien lähtökohtiensa konkretisoimiseksi. Esimies voi pitää työyhteisölleen johtamispuheen, jossa hän ilmaisee itselleen tärkeät asiat ja odotuksensa.

Lähijohtajuus rakentuu suhteissa ja on suhteiden rakentamista. Johtajan tapa rakentaa suhteita ja suhtautua ihmisiin ja asioihin on mallina muille. Kirjoittajien mukaan lähijohtaja joutuu jatkuvasti kysymään itseltään, ketä hän palvelee, ja miten olla riittävän hyvä johtaja itselleen ja muille. Tarvitaan itsetuntemusta ja tukiverkostoja kuten työnohjausta.

Jussi Onnismaa

Dosentti, työnohjaajakouluttaja Helsingin yliopisto, Palmenia 